\title{
Impacts of farmer field schools in the human, social, natural and financial domain: a qualitative review
}

\author{
Henk van den Berg ${ }^{1}$ (D) - Suzanne Phillips ${ }^{2} \cdot$ Marcel Dicke $^{1}$ (D) Marjon Fredrix ${ }^{2}$
}

Received: 17 January 2020 / Accepted: 8 May 2020 / Published online: 19 May 2020

(C) The Author(s) 2020

\begin{abstract}
The Farmer Field School (FFS) is a widely used method seeking to educate farmers to adapt agricultural decisions to diverse and variable field conditions. Out of 218 screened studies, 65 were selected to review the impact of the FFS. An analytical framework was developed with effects (outputs, outcomes and impacts) arranged according to the human, social, natural and financial domains. Impacts on non-participants of the FFS were addressed as peripheral effects. The FFS demonstrated its potential to enhance human, social, natural and financial capital of rural communities. Human capital was built in the form of critical thinking, innovation, confidence, and quality of life. Effects on social capital included mutual trust, bonding, collective action, networking, and emancipation. Natural capital was enhanced through improvements in field practices, food production, agricultural diversification, and food security. Financial capital was enhanced through increased income and profits, savings and loans schemes, with a potential to reduce poverty. The available body of evidence was unbalanced across the capital domains, providing high coverage of the natural domain but low coverage of the human, social and financial domains. In-depth case studies are needed to elucidate the interactions between livelihood assets, and the influences of the policy, institutional and external environment, in order to adjust FFS interventions aiming to optimize their impacts. Considering the positive effects the FFS can have on rural livelihoods, the FFS has potential to contribute to achieving the Sustainable Development Goals. However, quality assurance of the FFS and a balanced evaluation across the capital domains require attention.
\end{abstract}

Keywords Farmer field school $\cdot$ Adult education $\cdot$ Sustainable rural livelihoods $\cdot$ Impact assessment

\section{Introduction}

With the Sustainable Development Goals, challenging targets have been set for agriculture, food security and conservation of natural resources (UN 2018). Attaining these targets depends to a large extent on the empowerment of rural people as agents of change (FAO 2017a). However, growth in human populations and economies in many low- and middle-income countries puts increasing demands on agricultural production

Electronic supplementary material The online version of this article (https://doi.org/10.1007/s12571-020-01046-7) contains supplementary material, which is available to authorized users.

Henk van den Berg

vandenberg.henk@gmail.com; henk.vandenberg@wur.nl

1 Laboratory of Entomology, Wageningen University, PO Box 16, 6700, AA Wageningen, The Netherlands

2 Plant Production and Protection Division, Food and Agriculture Organization, Rome, Italy and land-use, whilst climate change is having disproportionate effects on food-insecure regions (FAO 2017b).

Rural populations of farmers and pastoralists rely for their livelihoods to an important extent on natural resources and ecosystem services. To cope with stress factors and changing circumstances caused by land degradation, population growth, ecosystem loss, climate change, and loss of natural resources, farmers must learn to adapt their practices to make optimal and sustainable use of available natural resources while adjusting to markets.

The Farmer Field School (FFS) is a widely used method in rural development seeking to educate farmers to adapt their agricultural decisions to diverse and variable field conditions (Pontius et al. 2002; FAO 2016a). The FFS was originally developed by the Food and Agriculture Organization (FAO) in the 1980s, in response to the negative side effects of the Green Revolution in Southeast-Asian rice production (Gallagher et al. 2009; Kenmore et al. 1995). Particularly, insecticide-induced pest outbreaks threatened food security, and demonstrated the inability of the prevailing 'technology 
transfer' strategy of agricultural extension to deal with those adverse effects. The FFS proved invaluable in implementation of integrated pest management by helping farmers make appropriate and timely decisions on crop management based on detailed field observations (Matteson 2000).

The FFS model was designed for groups of farmers who meet routinely with a trained facilitator in practical, fieldbased sessions during an entire production cycle (Pontius et al. 2002). Ecological learning, systems analysis, and field experimentation were emphasized in the curriculum to enable adaptation and innovation by farmers as individuals or groups (FAO 2016a). The FFS has been adopted for use in crops, livestock and fisheries, and spread from Asia to over 90 countries world-wide (Braun et al. 2006; Waddington et al. 2014). FAO continues to support FFS in the different regions, through expertise, networking and funding. In the meantime, a range of other organizations and agencies, which include farmer organizations, local and national governments, ngo's, and bilateral and international agencies, have adopted the FFS methods to advance the cause of rural development (FAO 2016a). A meta-analysis of FFS impact studies published until 2012 found that, in general, there has been a significant increase in knowledge about beneficial farming practices among FFS graduates (Waddington et al. 2014). Furthermore, the FFS decreased pesticide use of participants by an average of $17 \%$ (in FFSs featuring integrated pest management), increased yields of FFS participants by an average of $13 \%$, and increased net revenues (profits) of FFS participants by an average of $19 \%$, relative to a comparison group; however, there was notable variation across populations and contexts (Waddington et al. 2014). (Waddington et al. 2014).

The methodological basis of the FFS has borrowed from several educational concepts, namely the experiential learning cycle (Kolb 1984), the learner-centred approach for adult education (Rogers 1969), and the framework for the technical, practical and emancipatory domains of learning (Habermas 1971; Pontius et al. 2002; Freire 1968). With these educational foundations of the FFS, a continued process of learning, action and empowerment by its participants was envisaged (Pontius et al. 2002). Accordingly, the FFS can be expected to have wide-ranging effects on rural livelihoods; effects that go beyond those of linear extension services. The importance of measuring the effects of the FFS in domains other than farming knowledge and agricultural outputs has frequently been highlighted (Tripp et al. 2005; van den Berg and Jiggins 2007; Braun et al. 2006; Braun and Duveskog 2008; Pontius et al. 2002). In this respect, the sustainable livelihoods approach provides a useful framework by defining livelihood assets in several domains.

The objective of this qualitative study is to review the available evidence on FFS effects across the human, social, natural and financial capital domains of the sustainable livelihoods approach (Scoones 1998), in order to inform operational programmes about the types and pathways of effects that can practicably be expected. Foreknowledge about these effects could help current and future FFS programmes to improve their interventions and evaluations. It was not the purpose of this paper to provide a meta-analysis. This review was part of a process to develop a new framework and guidance for evaluation of the FFS (FAO 2019).

\section{Methods}

\subsection{Selection criteria and search method}

A literature search was delimited to studies published from 2005 to 2017; this period succeeded the period of the previous review commissioned by FAO (Van den Berg 2004); this was also the period during which the highest number of FFS impact studies have been published.

The search method consisted of a Scopus search over the period 2005-2017 for the phrase 'farmer field school' in the title, abstract or keywords of publications (TITLE-ABS-KEY 'farmer field school'), yielding 218 hits on 16 March 2018. Studies that used another name for the FFS, for example, 'pastoralist field school', were not included. Step-wise screening of these hits yielded 122 hits based on title, 87 based on abstract, and 45 based on content. Supplementary studies were located through FAO's Knowledge Repository Archive of the Global Farmer Field School Platform (http://www.fao.org/ farmer-field-schools/knowledge-repository/en/), with search term 'impact', through cross references, and through direct requests for documented studies from FAO's network of FFS projects and programmes; these studies were submitted to the same screening procedure.

Selection criteria were that a study must have adequately described methods, and provide convincing results on outputs, outcomes or impacts (collectively called 'effects'), or a lack thereof, in the human, social, natural and financial domains. Outputs are defined as the immediate results associated with the intervention, which in case of the FFS are the knowledge and skills gained. Outcomes are the short term (outcomes-1) or medium term (outcomes-2) consequences of the outputs in terms of changes in behaviour and actions that result from the use of the outputs. Impacts are the long-term consequences of the outcomes.

Care was taken not to judge studies based on the size of effects (e.g. no impact versus large impact), in order to reduce bias, and to consider a broad range of impact types. Studies reporting quantitative data (e.g. on agricultural practices or crop yield) were selected only when measures were in place to deal with selection bias of FFS participants vis-à-vis the control group (e.g. through difference-in-differences analysis, propensity score matching, or multivariate analysis), or, if 
quantitative data were supplemented by qualitative data to provide triangulation of results.

It proved difficult to obtain sufficient information about the quality of the FFS intervention, for example, to differentiate between genuine FFSs and those that did not use the educational principles of the FFS. Consequently, the selection of studies was not based on the quality of the intervention, or on the adherence to the core FFS principles (FAO 2016a). The available documentation suggested that eight out of 65 studies were leaning towards lecture- and demonstration-type interventions as opposed to the genuine FFS. The duration and intensity of the FFS varied according to the crop cycle, from weekly sessions during a threemonth rice crop season, to monthly meetings over a twelvemonth period in tea. Moreover, there were six studies in which interventions such as input credit, savings \& loans support, and farmer business schools were offered in addition to the core intervention of the FFS.

Altogether, 65 studies were selected as the sample for this review, each of which is summarized in the online Supplementary Material. By region, 29 studies were from sub-Saharan Africa, 29 from Asia, 7 from Latin America, and none from the Middle East or Europe.

\subsection{Analytical framework}

For the purpose of the review, an analytical framework was developed with outputs, outcomes and impacts of the FFS. These effects were arranged in four quadrants according to four capitals (human, social, natural and financial) as proposed in the original framework for sustainable rural livelihoods (Scoones 1998). Later modifications of the sustainable livelihoods approach identified a fifth capital, the physical capital (DfID 1999). However, in the case of the FFS, the effects on physical capital can be adequately accommodated as 'assets' under the financial capital (Pontius et al. 2002). The analytical framework for this review is presented in Fig. 1, which has been based on previous versions (FAO 2016a; Van den Berg 2004).

Intersecting the four quadrants are concentric circles that represent the causal chain of outputs, outcomes, and impacts, according to the available information in the selected studies. The causal chain is indicated in each of the four capitals, which is useful for planning evaluations. However, the division into four capitals also has its limitations because, in practice, the causal pathways may be more complex due to the interplay between the different domains. For example, improved farming practices are contingent upon skills in the natural domain, but may also be influenced by confidence in the human domain, collective action in the social domain and profits in the financial domain. Consequently, it is important to collect and evaluate results in all capital domains. Most of the 65 individual studies presented results in only one or a few of the four capitals, and presented only parts of the causal chain.

\section{Results}

The majority of studies reported positive effects of the FFS; a minority reporting neutral effects (i.e. lack of effect) (Table 1). By capital domain, positive effects were reported in 23 out of 25 instances (92\%) in the human domain; 41 out of 50 instances $(82 \%)$ in the social domain; 96 out of 121 instances (79\%) in the natural domains; and 14 out of 20 instances (70\%) in the financial domain. Many studies reported more than one type of effect.

Studies rarely reported a negative effect of the FFS, which occurred for example where the FFS led to higher labour costs. Most studies reported on natural capital; fewer studies reported on social capital; and least studies reported on human capital or financial capital. Moreover, most studies concentrated on outputs and outcomes, with few studies addressing impacts.

\subsection{Human capital}

Human capital is the skills, knowledge, ability to labour and good health and physical capability for the successful pursuit of different livelihood strategies (Scoones 1998). Inasmuch as being an adult-educational approach (Röling 2002), based on educational concepts (Kolb 1984; Freire 1968), the FFS is expected to build up human capital. In theory, this set of concepts contributes to human capital, over and beyond an increase in knowledge only(Waddington et al. 2014). These educational concepts were intended to foster critical thinking, leading to experimentation, innovation, improved decisionmaking and exploration which, in turn, may raise people's confidence and motivation, and result in improvements in the quality of life (Fig. 1). Remarkably, only a minority of available studies reported on the effects on human capital, beyond the effect on knowledge.

\subsubsection{Critical thinking, experimentation, innovation}

In a study from Kenya, farmers reported that after graduating from the FFS they started questioning previous assumptions or cultural beliefs, and reflected critically on the results of their own observations and experimentation (Duveskog et al. 2011; Friis-Hansen and Duveskog 2012). For example, graduated farmers placed greater reliance on their empirical field observations of crop performance than on the myth that crop failure was the result of witchcraft.

Another study from Kenya showed that farmers learned to improve field practices by making field observations, record keeping, and changing their attitude towards conserving water and soil; the critical reflection skills were developed in male farmers, but less in female farmers, which was attributed to women's heavy workloads (Najjar 2008). In another part of Kenya, FFS alumni groups reported a varying degree of 
Fig. 1 Analytical framework of the FFS, showing the generic skills, outputs, outcomes and impacts arranged in quadrants according to the human, social, natural and financial capitals of the sustainable livelihoods framework. The arrows between the four capital domains signify the interplay of effects that can take place between the domains, as explained in the text
Table 1 Number of studies reporting positive, neutral or negative effects according to each identified effect type

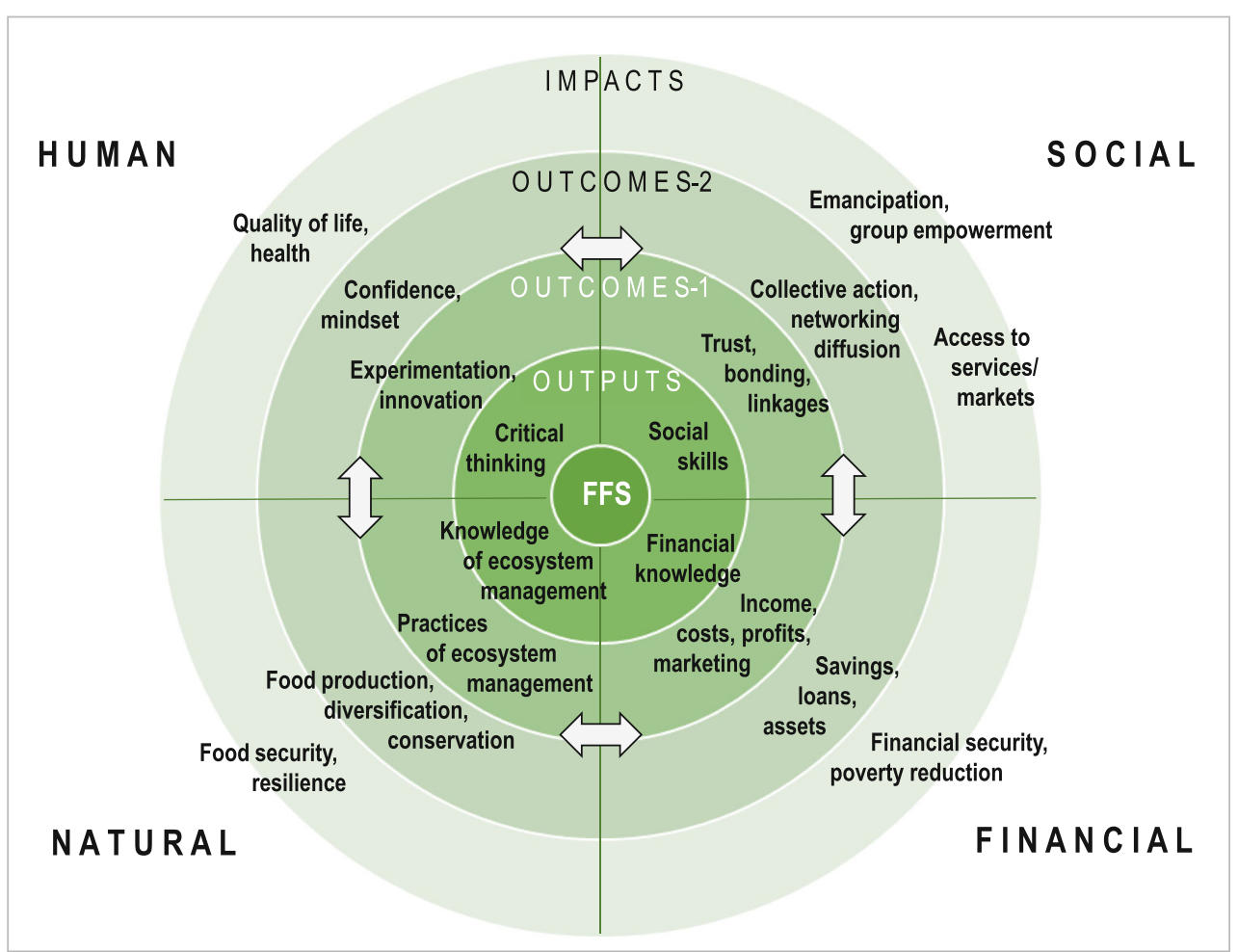

\begin{tabular}{|c|c|c|c|c|c|c|}
\hline \multirow[b]{2}{*}{ Domain } & \multirow[b]{2}{*}{ Effect type } & \multirow[b]{2}{*}{$\begin{array}{l}\text { Effect } \\
\text { level }\end{array}$} & \multicolumn{4}{|c|}{ Number of studies } \\
\hline & & & $\begin{array}{l}\text { Positive } \\
\text { effect }\end{array}$ & $\begin{array}{l}\text { Neutral } \\
\text { effect }\end{array}$ & $\begin{array}{l}\text { Negative } \\
\text { effect }\end{array}$ & Total \\
\hline \multirow[t]{4}{*}{ Human } & Critical thinking & Output & 3 & 0 & 0 & 3 \\
\hline & Experimentation, innovation & Outcome-1 & 6 & 0 & 0 & 6 \\
\hline & Confidence, mindset & Outcome-2 & 6 & 0 & 0 & 6 \\
\hline & Quality of life & Impact & 8 & 2 & 0 & 10 \\
\hline \multirow[t]{5}{*}{ Social } & Social skills & Output & 7 & 0 & 0 & 7 \\
\hline & Trust, bonding, linkages & Outcome-1 & 8 & 0 & 0 & 8 \\
\hline & $\begin{array}{l}\text { Collective action, networking, } \\
\text { diffusion }\end{array}$ & Outcome-2 & 17 & 7 & 0 & 24 \\
\hline & $\begin{array}{l}\text { Emancipation, group } \\
\text { empowerment }\end{array}$ & Impact & 6 & 2 & 0 & 8 \\
\hline & Access to services, markets & Impact & 3 & 0 & 0 & 3 \\
\hline \multirow[t]{6}{*}{ Natural } & $\begin{array}{l}\text { Knowledge of ecosystem } \\
\text { management }\end{array}$ & Output & 25 & 0 & 0 & 25 \\
\hline & $\begin{array}{l}\text { Practices of ecosystem } \\
\text { management }\end{array}$ & Outcome-1 & 32 & 6 & 0 & 38 \\
\hline & Food production & Outcome-2 & 22 & 10 & 0 & 32 \\
\hline & Diversification & Outcome-2 & 3 & 1 & 0 & 4 \\
\hline & Conservation & Outcome-2 & 11 & 7 & 1 & 19 \\
\hline & Food security, resilience & Impact & 3 & 0 & 0 & 3 \\
\hline \multirow[t]{5}{*}{ Financial } & Financial knowledge & Output & 0 & 0 & 0 & 0 \\
\hline & $\begin{array}{l}\text { Income, costs, profit, } \\
\text { marketing }\end{array}$ & Outcome-1 & 12 & 3 & 1 & 16 \\
\hline & Savings, loans, assets & Outcome-2 & 0 & 1 & 0 & 1 \\
\hline & Financial security & Impact & 0 & 0 & 0 & 0 \\
\hline & Poverty reduction & Impact & 2 & 1 & 0 & 3 \\
\hline
\end{tabular}


experimentation and innovation taking place among alumni groups in their own fields, for example farmers picked up how to design comparative field plots on crop varieties or monoversus mixed cropping (Machacha 2008). FFS training activities in smallholder tea farming contributed to graduated farmers conducting field experiments in tea and in other commodities (Waarts et al. 2012). Compared to the baseline situation, the number of experimenting farmers and the variety of experiments increased in the years after training; moreover, the percentage of farmers who experimented more than doubled for FFS alumni but decreased in the control group (Waarts et al. 2012). In a study in Nepal, farmers stated that the FFS helped them to explore and discover new economic and educational opportunities (Westendorp 2012).

\subsubsection{Confidence, mindset}

In-depth interviews and direct observations in Kenya suggested that the FFS helped farmers to gain confidence in their farming activities; they became more motivated and proactive in their planning due to the FFS. Before the FFS, people's mindset was reportedly more passive, people had lower self-esteem and confidence, a sense of fatalism and a strong attachment to traditional beliefs, practices and taboos (Duveskog et al. 2011; Friis-Hansen et al. 2012). In the Kenyan example, FFS alumni described a change in mindset, essentially transforming from a passive and fatalistic attitude into one of confidence, critical thinking, and aspirations. The respondents related these positive attributes to a greater sense of work ethic and initiative taking. These respondents also reported more optimism, happiness and pride as consequences of their participation in the FFS (Duveskog et al. 2011).

In another study from Kenya, every person interviewed mentioned how he or she had gained more confidence since the FFS, demonstrated through interactions with neighbouring farmers and public speaking in front of a group (Machacha 2008). Likewise, an evaluation conducted in Bangladesh indicated that the FFS raised participants' confidence, in particular among women by increasing their role in household-level decision making (DANIDA 2011).

\subsubsection{Quality of life}

The quality of life is generally defined as the standard of health, comfort, and happiness experienced by an individual or group, but this standard is dependent on culture and society. Questionnaire data gathered among Kenyan tea farmers before and after the FFS indicated a significant increase in how satisfied respondents were about family health, family welfare, and in the possibility to send children to school (Waarts et al. 2012), suggesting an improvement in the overall quality of life. In interview data from another study in Kenya, respondents reported an improved outlook on life as a result of participating in the FFS, manifested in a greater sense of optimism and happiness about farming (Duveskog et al. 2011).

With respect to human health, the FFS has potential to improve health, for example, by reducing pesticide poisoning incidences, by improving family nutrition and by addressing pertinent health issues, wherever such topics are included in the FFS curriculum. A number of studies on the FFS on IPM demonstrated substantial but variable reductions in pesticide poisoning cases, or poisoning signs and symptoms. These reductions were associated with a reduction in pesticide applications, the selection of less toxic products or the use of improved methods of personal protection (Chhay 2017; Cole et al. 2007; Morales-Abubakar et al. 2013; FAO 2016b; Mancini et al. 2009; Jørs et al. 2014), but some studies found no effect of the FFS on pesticide applications (see 3.3). There was also a positive effect of the FFS on the diversity of food and nutrition at household level (DANIDA 2011; Weinhardt et al. 2016; Doocy et al. 2017; Kuria 2014).

\subsection{Social capital}

Social capital is the social resources (e.g. networks, social claims, social relations, associations) upon which people draw when pursuing different livelihood strategies requiring coordinated actions (Scoones 1998; Pretty and Ward 2001; Coleman 1988). Social capital gives the community members additional meaning, power and opportunities as compared to the situation where individuals do not interact. The FFS model purposely adopted a group approach to stimulate farmers supporting each other, gain a voice, provide peer support, and strengthen their associations (Pontius et al. 2002). In theory, the social skills created through the FFS could nurture trust, bonding and linkages, which could lead to collective action, networks and farmer associations, and contribute to emancipation, group empowerment, and improved access to services and markets (Fig. 1).

\subsubsection{Social skills}

In only few studies, FFS alumni have been interviewed about their social skills. In Kenya, farmers reported that they had experienced a reduced shyness after the FFS, with better ability to express themselves (Duveskog et al. 2011; Najjar 2008). In Nepal, women farmers reported that they felt empowered by the FFS through the group work, collective singing, and by their speaking in front of the group (Westendorp 2012). In Cameroon and Ghana, questionnaire data suggested that cocoa farmers improved their social skills such as punctuality, being able to speak more confidently in public, listening to others without interrupting and respecting the opinions of others (David 2007; David and Asamoah 2011). The FFS increased the ability of Kenyan tea farmers to help their neighbours and to talk in front of the group, as compared to the baseline (Waarts et al. 2012). 


\subsubsection{Trust, bonding, linkages}

A quantitative multi-country study in Kenya, Tanzania and Uganda, using questionnaires, indicated a positive effect of the FFS on gender equity and trust (roles in decision making and leadership, lack of conflict, trust in villagers and farmer groups), and on household decision-making (related to farming, education, health, expenditure), as compared to the control group (Friis-Hansen and Duveskog 2012). However, details on the actual questions were not provided. The data were obtained approximately 5 years after completion of the FFS, suggesting a lasting impact(Friis-Hansen and Duveskog 2012).

A qualitative study in Kenya showed a large variation between groups of FFS alumni, with some groups being more cohesive and active than others. The results suggested several factors determining 'group viability'; for example, older groups were more independent than newly established groups, and groups with members living close-by were more cohesive than groups with more dispersed members (Machacha 2008). In Cameroon, farmers who graduated from cocoa FFSs explained that the goal of the farmer group was to encourage the sharing of ideas and encourage each other to use good production methods (David 2007), indicative of an emphasis on group building.

In Nepal, women farmers felt social support and solidarity in the weekly group sessions and collective activities of the FFS (Westendorp 2012); this support and solidarity has been labelled as the 'social-capital route to empowerment' (Bartlett 2008). The FFS reportedly created new interactions between farmers, thus breaking with strong traditions of segregation according to caste, gender, or religion (Westendorp 2012).

Among Kenyan tea farmers, $91 \%$ of FFS alumni expected that the group would continue after graduation (Waarts et al. 2012), but after several years it was reported that half of the groups had actually continued (Waarts et al. 2016). An evaluation study in Bangladesh concluded that half of FFS units had led to functioning farmer clubs, which is indicative of continued group meetings or group activities (DANIDA 2011). However, focus group discussions suggested that the clubs had not contributed significantly to gender equality in leadership and decision-making, with club activities mainly decided and driven by men (DANIDA 2011).

In conclusion, most of the available evidence suggests that the FFS generated an increased trust and bonding, in certain contexts breaking the barriers of ethnicity and gender.

\subsubsection{Collective action, networking}

The group-approach of the FFS encourages farmers to continue and expand their activities undertaken together as a group in the period after the FFS. Unfortunately, there is a limited number of studies describing or quantifying the level of collective action resulting from the FFS. In Kenya, where interventions focused on collective action on commercialization of agriculture, and marketing of produce, these effects were higher among FFS alumni as compared to the control group; however, similar interventions in Tanzania or Uganda did not produce these effects (Friis-Hansen and Duveskog 2012).

FFS alumni in Western Kenya explained how the purchase of farm inputs had been a major constraint for individual farmers and that, after the FFS, they developed a cooperative arrangement for purchase of inputs for all members (Machacha 2008). Following the FFS, interviewed groups in Uganda embarked collectively on commercial production of cash crops and on other collective income-generating activities, such as poultry production and zero grazing of livestock (Isubikalu 2007).

Another study in Kenya reported the collective use of crop rotation for pest management by alumni groups in high potential areas, or collectively planting trees along river banks to conserve soil, which was attributed to the FFS (Najjar 2008). A study from Central and Eastern Kenya reported that commercial activities implemented jointly by FFS group members were the driving force for sustaining the group activities (de Jager 2007). In Peru, a programme on coffee FFS led to the development of a producer organization (Van Rijn et al. 2012). Other examples of collective actions by FFS graduates are the mobilization of savings schemes (Westendorp 2012), and groups applying for financial support for their joint field activities (Mweri 2005). Moreover, pastoral field schools in Eastern Africa reportedly contributed to peace-building between clans or tribes (Hoeggel and Mbeyale 2014).

Several studies described how farmer networks emerged spontaneously as a result of the FFS. In Cambodia, FFS alumni formed associations and facilitator networks to provide services to local initiatives that use the FFS on IPM (Chhay 2017). In Kenya, district-level FFS networks were described from Bungoma District (Machacha 2008) and Taita Tavete District (Mweri 2005), which had emerged as farmer-driven activities seeking to sustain the implementation of the FFS beyond the end of the programme (Machacha 2008).

Another study described that networks of FFS alumni had developed with their own revolving fund and loans, and conducted self-sponsored outreach FFS activities at the village level (Mweri 2005). Also, FFS networks reportedly engaged in marketing of produce, and collaborated with government programmes and researchers (Machacha 2008; Mweri 2005). In one study, a FFS network could not be sustained because it could not effectively link farmers to the market due to lack of storage rooms, infrastructure and marketing skills (Najjar 2008). Some respondents mentioned they left the network because they did not benefit from it (Najjar 2008).

In conclusion, various examples are available of collective action and networking that emerged from the FFS. It remains unknown how common those initiatives were in the sampled programmes. 


\subsubsection{Diffusion}

A topic of frequent study has been the diffusion of outcomes and impacts of the FFS to other farmers who did not participate in the FFS. Unlike the extension strategy of technology transfer, the FFS approach was not built on the concept of diffusion (FAO 2016a). Nevertheless, a diffusion effect would potentially expand the scale of impact of the FFS. Diffusion has typically been studied by comparing the outcomes between three groups of farmers: FFS graduates, 'exposed' neighbouring farmers, and the outside control group (from non-FFS villages).

Ten studies showed a positive diffusion effect in terms of knowledge, practices or yields (e.g. (Settle et al. 2014; Witt et al. 2008; Wu 2010; Jørs et al. 2016) and seven studies showed no diffusion effect (e.g. (Burger et al. 2015; Guo et al. 2015; Cavatassi et al. 2011; Khan et al. 2007; Praneetvatakul and Waibel 2006). Some studies demonstrated diffusion of knowledge (Waarts et al. 2016; Rebaudo and Dangles 2011). In Bangladesh, there was evidence of diffusion of simple practices, such as use of a crop variety, but not for complex IPM practices (Ricker-Gilbert et al. 2008). A study on SRI indicated that a substantial proportion of nonFFS farmers within FFS villages benefited in some way from the intervention, suggesting that diffusion of this highly visible technology took place (Kabir and Uphoff 2007).

Cotton farmers in China reduced their pesticide use and increased their yields due to the FFS, while neighbouring farmers reduced their pesticide use in the short term but, unlike for FFS graduates, this effect was not sustained (Wu 2010). A short-term diffusion effect on pesticide use was also observed in Nepal (Regmi et al. 2014). Conversely, in Mali, data on the purchase of pesticides for cotton production collected in a non-experimental setting suggested a strong diffusion effect in the medium term (Settle et al. 2014). A study in Bolivia demonstrated a diffusion effect on pesticide handling and self-protection that was sustained over a number of years (Jørs et al. 2016).

Spatial proximity and kinship relationships were found to be key to diffusion of information on IPM (Palis et al. 2005; Palis 2006). Moreover, diffusion may be enhanced by clustered placement of FFS units within the same areas (the socalled 'foci-model' (FAO 2016a)), whereby FFS graduates become more common. Data from Senegal suggest that villages with a high proportion of FFS graduates had better communication networks than those with few graduates, resulting in more dissemination of information to non-FFS farmers (Witt et al. 2008; Pemsl et al. 2006). Clustered placement of FFS units has potential to enhance diffusion effects.

\subsubsection{Emancipation, group empowerment}

Several studies reported on effects of emancipation and group empowerment. Emancipation implies the attainment of social and political rights by a group or section of society that was previously marginalized or excluded; group empowerment takes place when social groups are able to take greater control of their lives within their socio-economic and political environment. In-depth interviews from Kenya showed important gender impacts of the FFS (Friis-Hansen et al. 2012). FFS graduates perceived a change in their gendered roles, with a shift in the power balance in favour of women. The mixedgender FFSs promoted equal participation and role sharing of men and women in group analysis, presentation and discussion, thus breaking with social taboos and customs regarding gender roles (Friis-Hansen et al. 2012; Duveskog et al. 2011). This process increased the role of women in agriculture and in decision-making, and also changed the way the men viewed the role of women. Furthermore, respondents indicated that domestic relations were improved and domestic conflict was reduced after the FFS (Friis-Hansen et al. 2012). In Eastern Kenya, qualitative data indicated that male participants of the FFS managed to break free from the stereotypic male role of alcohol abuse and idling in the community, becoming more involved in farming (Najjar 2008).

Similarly in Bangladesh, the FFS boosted women's selfconfidence and reportedly contributed to improved interhousehold relations between men and women, with increased involvement of women in decision-making regarding production and income (DANIDA 2011). The same study reported that critical socio-cultural problems that hinder emancipation (e.g. child labour, gender-based violence) were not given due attention in FFS sessions (DANIDA 2011).

In-depth interviews among FFS graduates in Nepal showed that positive changes in gender relations and gender roles at household level were common after the FFS, with women increasing their role in decision-making (Westendorp 2012). Women expressed they felt empowered through the FFS, and attributed this empowerment primarily to group dynamics; not to the discovery-learning process (Westendorp 2012). Women explained that they gained a voice in the group, and became confident to interact with like-minded people in the weekly FFS sessions. Nevertheless, the FFS in Nepal did not adequately address existing problems of discrimination and social exclusion in the community according to caste and gender (Westendorp 2012). Kitchen gardens, which were promoted as a component of the FFS for Kenyan tea farmers, were also reported to lead to empowerment of women, by having their own 'projects' and their own produce (Waarts et al. 2012).

\subsubsection{Access to services and markets}

A quantitative study among FFS graduates in Kenya, Tanzania and Uganda, suggested impact of the FFS on farmer's access to agricultural services five years after training (Friis-Hansen and Duveskog 2012). In each country, a larger fraction of alumni, as compared to the control group, had 
obtained agricultural advice or assistance over the previous two years. FFS farmers from Kenya engaged more with markets than control farmers, as indicated by their sale and processing of products, and were more often involved in collective marketing; the data from Tanzania and Uganda were inconclusive in this regard (Friis-Hansen and Duveskog 2012). A study in Nepal found that FFS farmers became more confident to raise their voice and demand services from the district agricultural office, such as inputs or training; farmers also claimed that through the FFS their relationship with the government had improved (Westendorp 2012).

In a study in the DR Congo, the FFS intervention took two years, and after completion, many farmers formed farmer business associations to improve access to credit and marketing (Doocy et al. 2018; Doocy et al. 2017). The study followed FFS households every six months for 3.5 years. At baseline, farmers sold their produce individually, but over time, farmers gradually adopted alternative marketing strategies. After baseline, $68 \%$ of FFS graduates adopted the use of joint negotiation at the level of the FFS, $56 \%$ adopted joint negotiation at the level of farmer business association, and 30\% adopted sales through agricultural collection centres; focus group discussions indicated that the diversification of marketing strategies was considered as beneficial by farmers (Doocy et al. 2017).

Summarizing, only a few studies addressed the access to services and markets. The available evidence suggested that the FFS improved the access to services and markets. Clearly, FFS programmes with focus on production can become more relevant if farmers (when interested) are able to learn how to sell their produce through marketing training (Doocy et al. 2017).

\subsection{Natural capital}

Natural capital is the natural resource stocks (e.g. water, soil, ecosystems) and environmental services (e.g. regulation of water, climate or plant pests) from which resource flows and services useful for livelihoods are derived (Scoones 1998). The FFS is expected to increase natural capital in several ways. The weekly field sessions of the FFS contribute to farmers' skills of ecosystem analysis (in agriculture or other disciplines). In theory, these skills result in improved food production, diversification and conservation. These outcomes could have an impact on food security, farmers' resilience to withstand environmental changes, and on the availability of environmental services (Fig. 1). In practice, the outcomes and impacts in the natural domain also depend on the interplay of effects in the other domains, such as innovation, collective action and financial savings.

\subsubsection{Skills and practices of ecosystem management}

Skills and knowledge have been extensively covered in the selected studies. Knowledge was studied in 25 out of 65 studies; skills of ecosystem management and decisionmaking have been studied alongside with knowledge, using simple test questions, or through self-reporting by respondents, but rarely through direct observations. In general, the results suggest that the FFS leads to more knowledge about natural systems (or ecological literacy) and ecosystem management skills, which is in line with meta-analysis results that established a positive effect of the FFS on knowledge about beneficial practices (Waddington et al. 2014).

For example, FFS alumni in China made pest management decisions in vegetables based on agroecosystem analysis and personal observations, whereas control farmers followed the advice from pesticide retailers or neighbours (Yang et al. 2008). Retrospective interviews among cocoa farmers in Ghana indicated that $79 \%$ of respondents observed and monitored conditions on their farms more closely after the FFS, making management decisions on the basis of field observations (David and Asamoah 2011). Moreover, in Kenya, farmers graduated from the FFS on dairy management self-reported that they became more knowledgeable and skilled in aspects such as artificial insemination, calf rearing, cow feeding (Makori 2007).

Practices of ecosystem management, mainly farming practices, have been addressed in the majority of studies on FFS outcomes and impacts (42 out of 65 selected studies). These practices included pest management practices (27 studies), agronomic practices (17 studies), fertilizer application (4 studies), varieties (2 studies), soil fertility/conservation (5 studies), water conservation ( 2 studies), kitchen gardening and reforestation (1 study each).

The overall results suggested that the FFS leads to use of beneficial farming practices, which concurs with the earlier meta-analysis results (Waddington et al. 2014). In 17 studies, the change in practices was measured by the rate of adoption of introduced practices or technologies. However, a limitation when using adoption rates is that they do not account for experimentation and innovation that distinguishes the FFS from technology transfer methods (Bartlett 2008).

Another 19 studies reported on pest management, with most studies showing a reduction (in some studies a drastic reduction) in pesticide use or spray frequency, indicative of more evidence-based decisions on crop protection; four of the studies showed no effect of the FFS on pest management practices, which could be due to the design or implementation of the intervention or due to other reasons (Labarta-Chávarri 2005; Lund et al. 2010; Rejesus et al. 2012; Cole et al. 2007). A study from Vietnam compared the FFS to a message-based intervention of the 'no early spray' (NES) campaign; there was a significant reduction in pesticide amounts used in FFS but not in NES farmers, suggesting that the FFS was more effective than NES (Rejesus et al. 2009).

In most studies, the change in practices was recorded shortly after the FFS, or the study did not indicate the time lag since the FFS. Only few studies examined longer-term effects. A 
study in East Africa conducted 5-7 years after the FFS found an increased uptake of improved crop varieties, vaccination of livestock, and improvement of soil fertility (Friis-Hansen and Duveskog 2012).

In conclusion, evidence shows that the FFS has generally led to an increase in knowledge and skills; most of the studies that reported on practices of ecosystem management showed positive change in the short and medium term.

\subsubsection{Food production}

Among the 65 selected studies, most studies featured singlecrop FFS, either for field crops or tree crops; one third of the studies featured FFS on multiple crops or livestock (Table 2). For the purpose of this review, the number of field crops was narrowed down to those that featured most frequently in the studies, which are rice, vegetables and tree crops.

Rice: Most studies on FFS in rice concentrated on the impact on pesticide use, or pesticide risk reduction, with only few studies reporting on production. In Indonesia, re-analysis of previous data from a large-scale programme in the 1990s reported positive short-term impact on yield among FFS and exposed farmers, but the impact declined in the medium term (Yamazaki and Resosudarmo 2008). A small-scale study from Vietnam suggested there was no impact on yield of rice; nevertheless, the control group was taken from within FFS villages, which may have been 'contaminated' by the intervention (Rejesus et al. 2012).

In Thailand, in an advanced rice production system, the FFS on IPM did not lead to an increase in yield but caused a significant net benefit due to reduced pesticide inputs (Praneetvatakul and Waibel 2006). In Cambodia, a convincing and durable impact was recorded on pesticide inputs, with approx. 50\% reduction measured six years after the FFS (Chhay 2017). Another study from Cambodia reported medium- and long-term reductions in pesticide inputs in rice after the FFS, including a long-term decline in pesticide shops; apart from the FFS intervention, pesticide policy had been reinforced (Morales-Abubakar et al. 2013; FAO 2016b).

In Myanmar, a study was conducted on the FFS in which the innovative rice-cultivation technology 'System of Rice Intensification' (SRI) was used. The results indicated a selfreported yield increase of $100 \%$ compared to a $48 \%$-yield increase among exposed (non-FFS) farmers. This suggests a major potential for agricultural impact in rice through the FFSSRI intervention, where conditions are amenable (Kabir and Uphoff 2007). SRI is a technology package for rice cultivation that differs in several respects from traditional methods (Thakur et al. 2016; Berkhout et al. 2015).

Vegetables: In China, farmers graduated from tomato FFS had $7 \%$ higher yields as compared to non-FFS farmers. A good match between characteristics of the FFS and non-FFS group suggested that selection bias was minor (Cai et al. 2016). Two studies from the Philippines presented evidence that onion FFS resulted in lower pesticide use, lower pesticide expenditure, increased profits, yet, the yield was the same (Sanglestsawai et al. 2015; Yorobe Jr et al. 2011).

In Ethiopia, FFS farmers showed an increased use of new vegetable varieties and improved sowing methods compared to the control group (Todo and Takahashi 2013). A study from Nepal demonstrated 70\% reduced pesticide use in FFS compared to control farmers, with results being most pronounced where follow-up support had been provided (Regmi et al. 2014). In India, FFS programmes on cabbage, cauliflower, eggplant and okra farmers showed an overall decline of $29 \%$ in pesticide applications, with large difference between crops, but there was no impact on the pesticide amount used, because FFS farmers replaced higher dosages of less toxic with lower dosages of more toxic pesticides (Sharma et al. 2015).

Tree crops: A study on cocoa FFS in Ghana showed that FFS graduates harvested $14 \%$ more than the control group one year after training, but FFS graduates required substantially more labour input for tree husbandry practices such as pruning and sanitation (Gockowski et al. 2010). A multi-country study on cocoa FFS showed yield increases of $32 \%, 34 \%, 50 \%$, and $62 \%$ in Ghana, Cote d'Ivoire, Nigeria, and Cameroon, respectively, for an intervention package that included an FFS followed by Farmer Business Schools, and with provision of an Input Credit Package. The FFS alone could not raise yields without the additional input provided (Tsiboe et al. 2016).

Two studies on tea FFS in Kenya showed that soon after the FFS there was no increase in yield or income as compared to the control group, despite adoption of improved practices (Waarts et al. 2012); however, two years later, yields had increased $15 \%$ more for FFS farmers than for the control group (Waarts et al. 2016).
Table 2 Number of studies covered the FFS on single field crops, tree crops, or multifaceted FFS on multiple crops or livestock ( $n=65$ studies $)$

\begin{tabular}{|c|c|c|c|c|c|c|c|c|}
\hline A. & Field crops & Number & B. & Tree crops & Number & $\mathrm{C}$. & Multifaceted & Number \\
\hline & Rice & 15 & & Cocoa & 4 & & Multiple crops & 9 \\
\hline & Vegetables & 13 & & Tea & 2 & & Multiple crops + livestock & 9 \\
\hline & Cotton & 8 & & Coffee & 1 & & Livestock & 3 \\
\hline & Potato & 4 & & & & & & \\
\hline & Legumes & 3 & & & & & & \\
\hline
\end{tabular}


Summarizing, the available recent evidence showed important reductions in pesticide use in rice and vegetables as a consequence of the FFS (thus reducing input costs), but increases in crop yield were variable. The FFS on SRI showed remarkable prospect for increasing rice yield. FFS on cocoa and tea, when given follow-up support, demonstrated substantial increases in yield.

\subsubsection{Diversification and conservation}

Multifaceted FFSs have been conducted that cover a combination of crops, livestock and other income sources (Table 2). In several cases, the multifaceted FFSs intended to increase the diversification of agricultural systems and income sources, or pursued the conservation of land, water, vegetation and biodiversity.

In Bangladesh, an evaluation study of a programme which promoted agricultural diversification, indicated that FFS households produced significantly more types of agricultural products than the control group, suggesting that the FFS led to diversification; also, the FFS households generated their income to a larger extent from livestock, fruits and vegetables than the control group (DANIDA 2011). In Kenya, the multifaceted FFSs led to adoption of various components of technologies such as composting, use of manure, soil conservation, and use of traditional vegetables and legumes (Bunyatta et al. 2006). Likewise, a study in Rwanda and Uganda noted a self-reported increase and diversification in food production due to FFS through promotion of kitchen gardens and vegetable production (Kuria 2014).

In Tanzania, an FFS-type intervention that provided individual farmer groups with three years of support, presented farmers with a basket of technology options such as techniques for soil and water conservation, new crop varieties, crop diversification and improved animal husbandry (Larsen and Lilleør 2014). The results indicated that FFS graduates had a higher number of crops, more fruit trees, and kept more improved breeds of livestock as compared to the control group, suggesting an impact on agricultural diversification. A study in Eastern Kenya that aimed towards diversification of food production, recorded that the FFS paid far less attention than intended to topics such as vegetables, legumes, livestock, poultry and beekeeping, but instead focused mostly on maize (Najjar 2008), suggesting institutional challenges to diversify agriculture. In Ethiopia, the FFS with an agroforestry component did not demonstrate a direct impact on reforestation soon after training, but household income from agriculture was increased (Todo and Takahashi 2013).

The spin-off development from crop-based into animalbased FFSs has occurred relatively recently and, hence, studies on pastoralism and livestock are few. One study evaluating the outcomes of Pastoral Field Schools in Eastern Africa reported that the introduction of hay making, vegetable production and rangeland management among pastoralists had been successful, indicating the prospects for diversification and conservation (Hoeggel and Mbeyale 2014), but the data need further verification. A study of the FFS to promote dairy farming demonstrated clear benefits in terms of milk production and dairy management (Makori 2007).

Conservation of biodiversity is an important objective in FFS interventions on IPM. A reduced reliance on chemical pesticides for crop protection helps restore natural balances in agroecosystems, thus allowing beneficial organisms to help suppress plant pests and diseases. The reductions in insecticide applications reported from FFS programmes in rice and vegetables, among other crops, have been associated with improvements in the Environmental Impact Quotient (EIQ), which is a proxy for impact on the environment (Kovach et al. 1992). Positive impact on EIQ has been reported from Nepal (Regmi et al. 2014), Pakistan (Khan et al. 2007; Pananurak 2010), Thailand (Praneetvatakul and Waibel 2006) and Vietnam (Morales-Abubakar et al. 2013). Conversely, no impact on EIQ was reported in studies from Ecuador (Cavatassi et al. 2011) and India (Sharma et al. 2015); in the latter case, the frequency of spraying declined after the FFS but the toxicity of selected products increased.

In conclusion, only few studies have captured the effects of the FFS on diversification and conservation. Out of those studies, the majority showed a positive effect on diversification and conservation (Table 1). However, none of the studies measured the actual impact on the abundance or diversity of beneficial organisms, soil health or water availability.

\subsubsection{Food security and resilience}

In a conflict-stricken region in DR Congo, a 55\% increase in the diversity of agricultural production practices, and in food and nutrition security indicators (HDDS and HFIAS (Swindale and Bilinsky 2006b, Swindale and Bilinsky 2006a; Coates et al. 2007)) was attributed to the FFS (Doocy et al. 2017). The intervention used an adapted model of the FFS, with provision of starter packages, and with technical support for individual farmer groups over a 2-year period to improve agricultural production practices. Despite the impact on food security, no effect was found on child nutritional status, thus highlighting the need for additional interventions to address this specific issue. A study from Malawi showed that an FFS model which included support for savings and loans, resulted in a $26 \%$ reduction in food insecurity indicators; this beneficial effect was sustained for at least three years (Weinhardt et al. 2016).

In Tanzania, another modified FFS-model with a threeyear intervention for individual farmer groups, showed positive effects on food security soon after the intervention which were associated with high uptake of introduced technologies, but the duration and costs of the intervention prevented 
upscaling (Larsen and Lilleør 2014). Similarly, an evaluation of programmes in Ghana, Malawi and Mali indicated that Farmer Field Business Schools, which is a modified version of the FFS developed by CARE International, together with savings-and-loans support and several other interventions, increased the perceived food security among graduated farmers (Weatherhead et al. 2016; Weatherhead 2016). In a study in Rwanda and Uganda, a nutrition component had been added to an ongoing FFS programme, but no impact was found on nutrition security, which was reportedly due to inadequate technical skills of facilitators and a lack of structural inclusion of the nutrition component, highlighting the importance of programme design and capacity building (Kuria 2014).

By resilience is meant the capacity to anticipate, respond and adapt to shocks and changes such as those posed by climate change and environmental degradation (Béné et al. 2016). The concept of resilience is increasingly recognized in FFS programmes on climate change adaptation and disaster risk management (FAO 2016a), to improve farmers' ability to cope with shocks or trends caused by droughts, floods, environmental degradation and conflict. However, tools for measuring resilience are still under development (Frankenberger and Nelson 2013; Sharifi 2016). Empirical evidence on resilience will be needed to inform the development of better targeted interventions (Frankenberger and Nelson 2013). Unfortunately, none of the 65 selected studies have attempted to assess resilience as an impact of the FFS.

In conclusion, studies on resilience are lacking, but available studies demonstrated that FFSs can improve food security, if investment is made in the form of an extended training model or with one or more supplemental interventions. Specific additional interventions or modifications may be needed to improve nutritional status in children.

\subsection{Financial capital}

Financial capital is the capital base (cash, credit/debt, savings, and other economic assets, including basic infrastructure and production equipment and technologies) which are essential for the pursuit of any livelihood strategy (Scoones 1998). The FFS is expected to contribute to financial capital on several fronts. In the FFS, financial skills can be learnt on how to keep track of expenditures and earnings, how to calculate yield and gross margins, and how to interact with markets. These skills help farmers manage their income and costs, and improve their profits. Farmers could thus build savings, take loans, and gain assets - either as individuals or as groups or cooperatives. These outcomes could lead to financial security, poverty reduction, and increased opportunities available to farmers (Fig. 1). In practice, the financial outcomes and impacts also depend on the interplay of effects in the other domains, such as the experimentation skills, improved practices of ecosystem management and group interactions.

\subsubsection{Income, costs, profits and marketing}

A number of studies have reported on changes in cost, income or profit as a consequence of participation in the FFS. Studies on cotton IPM in China demonstrated that the FFS caused convincing increases in gross margin (excluding the value of family labour) and household income of cotton farmers, through a major reduction in the cost of insecticide application and marginally increased crop yield (Pananurak 2010; Wu 2010). In Thailand, a study on IPM in rice did not show a significant effect of the FFS on gross margin, despite reductions in pesticide use (Praneetvatakul and Waibel 2006), while in Cambodia, a study on IPM in rice demonstrated an increase in net profit attributed to the FFS (Chhay 2017).

A multi-country study in East Africa showed that participation in the FFS was associated with increased productivity and, on average, a $61 \%$ increase in household income (Davis et al. 2012). A study in Kenya suggested that the FFS on tea increased family income and the number of income sources (Waarts et al. 2012). Increased income was also reported in studies from Ecuador (Cavatassi et al. 2011), Ethiopia (Todo and Takahashi 2013), Nepal (Regmi et al. 2014), and the Philippines (Sanglestsawai et al. 2015; Mataia et al. 2015). In Nicaragua, the FFS on beans showed no impact on income, but additional evidence indicated the inferior performance of the FFS (Labarta-Chávarri 2005).

Only few studies addressed the impact of the FFS on marketing. In Kenya, five to eight years after the FFS, it was found that FFS graduates were more likely to sell their produce, and engage in processing or value addition, as compared to the control group (Friis-Hansen and Duveskog 2012). Several studies of the FFS noted that marketing was not adequately addressed in the FFS curriculum. In Eastern Kenya, the FFS focused on subsistence crops, without a marketing component, but participants appeared to be more interested in marketing as a group and gaining access to the market (Najjar 2008). In a study in Western Kenya, FFS alumni stated that they had lacked training on processing, value adding and marketing (Machacha 2008). Likewise in Ethiopia, it was reported that processing and marketing were not given due attention in coffee FFS (Endalew 2009).

In Bangladesh, where the FFS curriculum did include a marketing component, the potential for income increase through marketing was demonstrated even among the poorest households who had very little or no land (DANIDA 2011). Nevertheless, limited progress was noted among alumni groups in terms of establishing market linkages and processing of produce, despite FFS graduates being more likely than the control group to receive marketing information from agricultural extension staff and farmer trainers (DANIDA 2011).

Summarizing, most but not all studies showed clear financial benefits of the FFS in terms reduced input costs, and increased income and profits. The impact of the FFS on 
marketing received little attention in the available studies, whilst there were indications that marketing was seldomly included in FFS training in the studies.

\subsubsection{Savings, loans and assets}

Savings, loans and assets contribute to the capacity of farming communities to cope with unexpected situations or expenses, and enable them to make investments. Several studies described locally-owned savings-and-loans schemes at village level, either as an FFS component or as a self-help follow-up activity of the FFS (Weinhardt et al. 2016; Weatherhead et al. 2016; DANIDA 2011; Hoeggel and Mbeyale 2014; Isubikalu 2007). The savings were generated through member fees or through sale of produce harvested from communal field plots (DANIDA 2011). These schemes enabled members to lend at affordable interest rates, for example, to purchase inputs at the onset of the crop season or to start up an enterprise.

In a multi-country study in East Africa, FFS graduates in Kenya and Uganda (but not in Tanzania) had approximately twice higher membership rates in savings-and-loans organizations, and were more likely to have a bank account, as compared to the control group (Friis-Hansen and Duveskog 2012); however, the study only partly addressed selection bias. In Eastern Africa, pastoralist Field Schools included the establishment of village savings schemes; these schemes presented the main financial source for investments in incomegenerating enterprises among graduates which, when successful, diversified the income sources and added financial assets into the scheme (Hoeggel and Mbeyale 2014). The savings schemes have been found to contribute substantially to social capital, building mutual trust and bonding (Hoeggel and Mbeyale 2014).

Concluding, inclusion of village savings-and-loans schemes in the FFS learning process has much prospect to increase financial capital among FFS graduates, particularly where infrastructure is poor. However, empirical evidence on the success and sustainability of these schemes is largely absent in the selected studies.

\subsubsection{Financial security and poverty reduction}

Financial security implies the access to financial resources needed for a decent standard of living. Financial security is determined by factors such as cash-equivalent assets, debt and access to credit. There are no known standards for measuring financial security (Lee and Kim 2016). Also, people may not disclose what they earn or have. Village savings-and-loans schemes promoted through the FFS are expected to raise financial security by providing social safety nets with easy access to credit when needed (FAO 2016a). However, none of the selected studies assessed whether such schemes made farmers and pastoralists financially more secure, or whether they increased people's livelihood options (e.g. schooling, mobility). In a study in DR Congo, farmers' use of financial services changed over the course of the two-year FFS intervention, from the use of informal credit to the use of savings, which suggests that farmers became financially more secure (Doocy et al. 2017).

Impact on poverty was assessed in two studies. In the first study, conducted in Kenya, Tanzania and Uganda, poverty was assessed using indicators of wellbeing. Self-reported poverty, as recorded in a questionnaire using poverty indicators, was lower among FFS graduates than among farmers who had not yet commenced the FFS in each country, suggesting that the FFS reduced poverty (Friis-Hansen and Duveskog 2012). Using asset-based poverty indicators (e.g. having a mobile phone, or good quality floor), a study in Tanzania found no significant impact of a modified FFS intervention on poverty at one year after the intervention, despite positive effects on food security (Larsen and Lilleør 2014).

Hence, limited evidence suggests that the FFS has potential to reduce poverty and financial vulnerability, but further studies looking at effects in the longer-term are needed.

\section{Discussion}

The available evidence showed that the farmer field school approach can affect multiple assets that influence people's livelihoods. In each of the four domains, the majority of studies demonstrated positive effects, which indicates that the farmer field school approach can benefit the human, social, natural as well as financial assets. Arguably, equal importance could be attached to these four assets, because people generally need each of these assets for their local livelihood strategies. Human and social assets could be seen as the 'drivers' for impacts in the natural and financial domains.

However, the amount of available evidence was unbalanced across the four domains and across the causal chain. There was high coverage in the literature of the natural domain, as far as data on knowledge and practices of ecosystem management, and food production, is concerned. Typically, these specific outputs and outcomes have been the focus of linear extension approaches that aimed for adoption of introduced technologies or methods. In the natural domain, coverage was low for outcomes such as diversification, and for impacts such as food security, resilience and ecosystems services. Few studies addressed social capital, whilst human capital and financial capital were poorest served by the available studies. Where studies did address the human, social or financial domain, the results indicated important benefits, for example, on confidence building, collective action, emancipation and poverty reduction.

The imbalance of studies across the four domains presents a research bias towards agricultural outputs and outcomes. Possible reasons for this bias are: a restricted scope of anticipated 
results in project logical frameworks; an under-appreciation of the importance of the livelihood assets among research teams; and the relative difficulty of measuring effects on human and social assets. Future studies should bring more balance into the evaluation of the FFS across the capital domains. Unravelling the cause-effect chain of the FFS and its components is a major challenge, for example where the FFS is part of a broader set of interventions or where contextual changes occur. Moreover, the study of impacts is challenged by the availability of suitable methods. For some parameters, methods or indicators have become available, such as for poverty reduction (Anonymous 2018), quality of life (Diener and Suh 1997), empowerment (Kabeer 1999; Alsop and Heinsohn 2005), and food and nutrition security (Swindale and Bilinsky 2006b; Swindale and Bilinsky 2006a; Coates et al. 2007). However, standard methods for assessment are lacking or under development for parameters such as emancipation, resilience, financial security, and access to markets (Frankenberger and Nelson 2013; Sharifi 2016).

Apart from the need for balance in studies on human, social, natural and financial assets, it is important to understand how these assets interact with each other, or how they are mutually supportive, for improvement of sustainable livelihoods. For example, FFS participation led to personal transformation, causing changes in gender roles and relations, and increasing economic development, which in turn reinforced people's self-confidence and status in the community (Duveskog et al. 2011). This example suggests an experiential learning cycle that led to transformations with benefits to human, social and financial assets. Moreover, the framework for technical, practical and emancipatory learning, which has been central to the FFS, envisaged a process of continued learning and problem solving, with an expanding scope of action (Pontius et al. 2002). Unfortunately, most of the available studies reported only fragmented outputs, outcomes or impacts of the analytical framework, without studying the interactions or cause-effect linkages between various outcomes and impacts. A few exceptions were studies that reported on the full causal chain in one or several domains (Duveskog et al. 2011; Westendorp 2012; Friis-Hansen and Duveskog 2012; Machacha 2008; DANIDA 2011).

The livelihood outcomes and impacts are contingent upon the external environment in which people live, over which they have limited or no control. These influences include variables such as climate change, population trends, economic trends, and political and institutional changes, which can diminish or enhance livelihood assets. Hereby, it is noted that the FFS has helped farmers to actively adapt their livelihood strategies to changing external variables, for example, by growing drought-resistant crops and adopting waterconservation practices in response to recurring droughts.

Moreover, the existing policy and institutional environment, including the agricultural extension system, and local culture, have an impact on the quality, acceptability, scope and scale of the FFS in helping farmers improve their livelihood assets and obtain equitable access to services and competitive markets. It is noteworthy that the FFS model inherently conflicts with the conventional technology-transfer paradigm. Hence, unless institutions and policy frameworks are made compatible with the FFS at higher levels, the FFS cannot be substantially scaled up (Röling 2002; Sherwood et al. 2012). In several instances, institutions had degenerated the FFS model, falling back to lectures and demonstrations, which was not according to the original purpose of the FFS. There were indications from a few countries that the FFS has been incorporated in national policy and national agricultural strategies (FAO 2016b; Settle et al. 2014), and where FFS projects have helped transform institutions by adopting a participatory approach of working with farmers (Westendorp 2012; Isubikalu 2007; Friis-Hansen 2008). However, in other cases, it was doubtful that a meaningful scale of FFS activities could be sustained without external project funding (DANIDA 2011), or competing interests among institutions forced the discovery-based methods of the FFS to make way for the dominant institutional paradigm of technology transfer (Sherwood et al. 2012).

Studying the interactions between livelihood assets, the influences of the external environment, and the effects of the existing policy and institutional environment, can provide insight into the impact pathways within the local context. Understanding these pathways and contextual influences will help countries or programmes enhance or modify their FFS interventions so as to optimize the impacts. Hence, in-depth case studies are necessary for further adaptation of the FFS approach.

A limitation of this review was that the quality of implementation of the FFS was rarely described in the selected studies. The selected studies included several that adopted the FFS brand name but that had apparently abandoned the core FFS principles regarding programme design, local ownership and ecological learning, as evidenced by their 'demonstration-type' interventions (see Supplementary Material). These shortcomings are likely to have underestimated the impacts of the 'genuine' FFS implemented according to its educational principles.

\section{Conclusions}

Based on the reviewed evidence, the FFS has demonstrated its potential to enhance human, social, natural and financial capital of rural communities, which is important because people generally need each of these assets for their local livelihood strategies. However, the available body of recent evidence was highly unbalanced across the capital domains, providing high coverage of the natural domain but low coverage of the human, social and financial domains, while emphasizing short-term outputs and outcomes rather than long-term 
impacts. Most studies reported only fragmented outputs, outcomes or impacts of the analytical framework. Hence, indepth case studies are needed to elucidate the impact pathways and local contextual influences, because these insights would enable enhancement or modification of the FFS interventions intending to optimize their impacts.

Considering the positive effects of the FFS on livelihood assets, the FFS has potential of making a vital contribution to achieving the Sustainable Development Goals. Quality assurance of the FFS, and well-planned evaluation studies that balance across the capital domains and that study interactions between the assets, will help achieve this potential.

Acknowledgements This work was supported by the Plant Production and Protection Division and Special Programme- 2 of the Food and Agriculture Organization of the United Nations. An anonymous reviewer is acknowledged for constructive comments which helped improve the manuscript. We thank Anne-Sophie Poisot, Emily Janoch, Deborah Duveskog, Gerd Walter-Echols, Jan Willem Ketelaar, Karl Deering, Kevin Gallagher, Peter Kenmore and Stefano Mondovi for valuable discussions and for providing useful materials.

\section{Compliance with ethical standards}

Conflict of interest $\mathrm{HvdB}$ and MD declare that they have no conflict of interest. SP and MF are employed by the Food and Agriculture Organization of the United Nations, an organization which has developed and promoted the Farmer Field School method.

Open Access This article is licensed under a Creative Commons Attribution 4.0 International License, which permits use, sharing, adaptation, distribution and reproduction in any medium or format, as long as you give appropriate credit to the original author(s) and the source, provide a link to the Creative Commons licence, and indicate if changes were made. The images or other third party material in this article are included in the article's Creative Commons licence, unless indicated otherwise in a credit line to the material. If material is not included in the article's Creative Commons licence and your intended use is not permitted by statutory regulation or exceeds the permitted use, you will need to obtain permission directly from the copyright holder. To view a copy of this licence, visit http://creativecommons.org/licenses/by/4.0/.

\section{References}

Alsop, R., \& Heinsohn, N. (2005). Measuring empowerment in practice: Structuring analysis and framing indicators: The World Bank.

Anonymous (2018). Microfinance: A Way to Help the Poor Build Assets. $\mathrm{http}: / /$ www.microfinance.com.

Bartlett, A. (2008). No more adoption rates! Looking for empowerment in agricultural development programmes. Development in Practice, $18,524-538$

Béné, C., Headey, D., Haddad, L., \& von Grebmer, K. (2016). Is resilience a useful concept in the context of food security and nutrition programmes? Some conceptual and practical considerations. Food Security, 8(1), 123-138.

Berkhout, E., Glover, D., \& Kuyvenhoven, A. (2015). On-farm impact of the system of Rice intensification (SRI): Evidence and knowledge gaps. Agricultural Systems, 132, 157-166.
Braun, A., \& Duveskog, D. (2008). The farmer field school approach History, Global Assessment and Success Stories. Unpublished IFAD Report.

Braun, A., Jiggins, J., Röling, N., van den Berg, H., \& Snijders, P. (2006). A global survey and review of farmer field school experiences. Wageningen: Endelea.

Bunyatta, D. K., Mureithi, J. G., Onyango, C. A., \& Ngesa, F. U. (2006). Farmer field school effectiveness for soil and crop management technologies in Kenya. Journal of International Agricultural and Extension Education, 13(3), 47-63.

Burger, N., Fu, M., Gu, K., Jia, X., Kumar, K. B., \& Mingliang, G. (2015). Assessing the impact of farmer field schools on fertilizer use in China. In 3ie Impact Evaluation Report 25. New Delhi: International Initiative for Impact Evaluation.

Cai, J., Shi, G., \& Hu, R. (2016). An impact analysis of farmer field school in China. Sustainability, 8(2), 137.

Cavatassi, R., González-Flores, M., Winters, P., Andrade-Piedra, J., Espinosa, P., \& Thiele, G. (2011). Linking smallholders to the new agricultural economy: The case of the plataformas de concertación in Ecuador. Journal of Development Studies, 47(10), $1545-1573$.

Chhay, N. (2017). The study on sustainable integrated pest management on rice in Cambodia. PhD thesis. Nagoya: Nagoya University.

Coates, J., Swindale, A., \& Bilinsky, P. (2007). Household Food Insecurity Access Scale (HFIAS) for measurement of food access: indicator guide. Food and Nutrition Technical Assistance Project (Vol. 34). Washington, DC: Academy for Educational Development.

Cole, D. C., Sherwood, S., Paredes, M., Sanin, L. H., Crissman, C., Espinosa, P., \& Munoz, F. (2007). Reducing pesticide exposure and associated neurotoxic burden in an Ecuadorian small farm population. International Journal of Occupational and Environmental Health, 13(3), 281-289.

Coleman, J. S. (1988). Social capital in the creation of human capital. American Journal of Sociology, 94, S95-S120.

DANIDA. (2011). Evaluation of the farmer field school approach in the agriculture sector Programme support phase II, Bangladesh. Copenhagen: Ministry of Foreign Affairs of Denmark.

David, S. (2007). Learning to think for ourselves: Knowledge improvement and social benefits among farmer field school participants in Cameroon. Journal of International Agricultural and Extension Education, 14(2), 35-50.

David, S., \& Asamoah, C. (2011). The impact of farmer field schools on human and social capital: A case study from Ghana. Journal of Agricultural Education and Extension, 17(3), 239-252.

Davis, K., Nkonya, E., Kato, E., Mekonnen, D. A., Odendo, M., Miiro, R., \& Nkuba, J. (2012). Impact of farmer field schools on agricultural productivity and poverty in East Africa. World Development, $40(2), 402-413$.

de Jager, A. (2007). Practice makes perfect: participatory innovation in soil fertility management to improve rural livelihoods in East Africa. $P h D$ thesis. Wageningen: Wageningen University.

DfID (1999). Sustainable livelihoods guidance sheets (Department for International Development). London.

Diener, E., \& Suh, E. (1997). Measuring quality of life: Economic, social, and subjective indicators. Social Indicators Research, 40(1-2), 189216.

Doocy, S., Cohen, S., Emerson, J., Menakuntuala, J., Rocha, J. S., \& Jenga_Jamaa_II_Study_Team. (2017). Food security and nutrition outcomes of farmer field schools in eastern Democratic Republic of the Congo. Global Health: Science and Practice, 5(4), 630-643.

Doocy, S., Emerson, J., Colantouni, E., Strong, J., Mansen, K. A., Caulfield, L. E., et al. (2018). Improving household food security in eastern Democratic Republic of the Congo: A comparative analysis of four interventions. Food Security, 10(3), 649-660. 
Duveskog, D., Friis-Hansen, E., \& Taylor, E. W. (2011). Farmer field schools in rural Kenya: A transformative learning experience. Journal of Development Studies, 47(10), 1529-1544.

Endalew, B. D. (2009). Effectiveness of farmer field school in promoting coffee management practices: The case of Jimma and Sidama zones. MSc thesis. Haramaya University,

FAO. (2016a). Farmer field school guidance document: Planning for quality programmes. Rome: Food and Agriculture Organization.

FAO. (2016b). Lasting IPM impact: Results from long-term studies on the impact of pesticide risk reduction farmer field schools in Cambodia and Vietnam. In DRAFT Version: 12 September 2016. Bangkok: Food and Agriculture Organization.

FAO (2017a). Food and agriculture. Driving action across the 2030 Agenda for Sustainable Development. Rome: Food and Agriculture Organization.

FAO. (2017b). The future of food and agriculture - Trends and challenges. Rome: Food and Agriculture Organization.

FAO. (2020). Monitoring, evaluation and learning in farmer field school programmes: A framework and toolkit. Rome: Food and Agriculture Organization.

Frankenberger, T., \& Nelson, S. (2013). Background paper for the expert consultation on resilience measurement for food security. Rome: Food and Agriculture Organization, and World Food Programme.

Freire, P. (1968). The pedagogy of the oppressed. New York: Seabury Press.

Friis-Hansen, E. (2008). Impact assessment of farmer institutional development and agricultural change: Soroti district, Uganda. Development in Practice, 18(4-5), 506-523.

Friis-Hansen, E., \& Duveskog, D. (2012). The empowerment route to well-being: An analysis of farmer field schools in East Africa. World Development, 40(2), 414-427.

Friis-Hansen, E., Duveskog, D., \& Taylor, E. W. (2012). Less noise in the household: The impact of farmer field schools on gender relations. Journal of Research in Peace, Gender and Development, 2(2), 44 55.

Gallagher, K. D., Ooi, P. A. C., \& Kenmore, P. E. (2009). Impact of IPM programs in Asian agriculture. In R. Peshin, \& a. K. Dhawan (Eds.), Integrated pest management: dissemination and impact (pp. 347358): Springer.

Gockowski, J., Asamoah, C., David, S., Gyamfi, I., \& Kumi, M. A. (2010). An evaluation of farmer field school induced changes in Ghanaian cocoa production. Journal of International Agricultural and Extension Education, 17(3), 43-56.

Guo, M., Jia, X., Huang, J., Kumar, K. B., \& Burger, N. E. (2015). Farmer field school and farmer knowledge acquisition in rice production: Experimental evaluation in China. Agriculture, Ecosystems \& Environment, 209, 100-107.

Habermas, J. (1971). Knowledge and human interests. Boston: Beacon Press.

Hoeggel, U., \& Mbeyale, G. (2014). Impact assessment of pastoralist field schools in Ethiopia. Kenya and Uganda: Swiss Agency for Development and Cooperation.

Isubikalu, P. (2007). Stepping-stones to improve upon functioning of participatory agricultural extension programmes: Farmer Field Schools in Uganda. PhD thesis. Wageningen: Wageningen University.

Jørs, E., Konradsen, F., Huici, O., Morant, R. C., Volk, J., \& Lander, F. (2016). Impact of training Bolivian farmers on integrated pest management and diffusion of knowledge to neighboring farmers. Journal of Agromedicine, 21(2), 200-208.

Jørs, E., Lander, F., Huici, O., Morant, R. C., Gulis, G., \& Konradsen, F. (2014). Do Bolivian small holder farmers improve and retain knowledge to reduce occupational pesticide poisonings after training on integrated Pest management? Environmental Health, 13(1), 75.
Kabeer, N. (1999). Resources, agency, achievements: Reflections on the measurement of women's empowerment. Development and Change, $30(3), 435-464$.

Kabir, H., \& Uphoff, N. (2007). Results of disseminating the system of rice intensification with farmer field school methods in northern Myanmar. Experimental Agriculture, 43(4), 463-476.

Kenmore, P. E., Gallagher, K. D., \& Ooi, P. A. C. (1995). Empowering farmers: Experiences with integrated pest management. Entwicklung \& Ländlicher Raum, 95(1), 27-28.

Khan, M. A., Iqbal, M., \& Ahmad, I. (2007). Environment-friendly cotton production through implementing integrated pest management approach. Pakistan Development Review, 46(4), 1119-1135.

Kolb, D. A. (1984). Experiential learning: Experience as the source of learning and development. Englewood Cliffs: Prentice-Hall.

Kovach, J., Petzoldt, C., Degni, J., \& Tette, J. (1992). A method to measure the environmental impact of pesticides. New York's Food and Life Sciences Bulletin, 192, 2-8.

Kuria, E. N. (2014). Integrating nutrition in farmer field schools in eastern Africa. Report on lessons learnt: MEAS Evaluation Series.

Labarta-Chávarri, R. A. (2005). Essays on the economic evaluation of integrated pest management extension in Nicaragua. PhD thesis: Michigan State University.

Larsen, A. F., \& Lilleør, H. B. (2014). Beyond the field: The impact of farmer field schools on food security and poverty alleviation. World Development, 64, 843-859.

Lee, J. M., \& Kim, K. T. (2016). Assessing financial security of lowincome households in the United States. Journal of Poverty, 20(3), 296-315.

Lund, T., Sæthre, M. G., Nyborg, I., Coulibaly, O., \& Rahman, M. H. (2010). Farmer field school-IPM impacts on urban and peri-urban vegetable producers in Cotonou, Benin. International Journal of Tropical Insect Science, 30(1), 19-31.

Machacha, A. (2008). Farmer field schools in Bungoma district of Western Kenya: A rapid appraisal. In Retrospective theses and dissertations, 15449. Ames: Iowa State University.

Makori, J. (2007). Influence of farmer field school extension approach on smallholders' knowledge and skills of dairy management technologies in Molo division, Nakuru District of Kenya. MSc thesis. Njoro: Egerton University.

Mancini, F., Jiggins, J. L. S., \& O'Malley, M. (2009). Reducing the incidence of acute pesticide poisoning by educating farmers on integrated pest management in South India. International Journal of Occupational and Environmental Health, 15(2), 143-151.

Mataia, A. B., Olivares, R. O., Manalili, R. G., Malasa, R. B., Litonjua, A. C., Redondo, G. O., et al. (2015). Impact of farmer field schoolPalaycheck ${ }^{\circledR}$ in the irrigated Rice areas in the Philippines. Philippine Journal of Crop Science, 40(3), 30-42.

Matteson, P. (2000). Insect pest management in tropical Asian irrigated rice. Annual Review of Entomology, 45(1), 549-574.

Morales-Abubakar, A. L., Arnst, R., Chung, D. K., Ketelaar, J. W., Pananurak, P., Praneetvatakul, S., et al. (2013). Empowering farmers to reduce pesticide risks. Bangkok: Food and Agriculture Organization.

Mweri, B. A. M. (2005). Up scaling farmer field schools: "A bushfire...?" Technographic studies on livelihoods and participation in FFS by small-holder farmers in coastal Kenya. MSc thesis. Wageningen: Wageningen University-Department of Social Sciences.

Najjar, D. (2008). Learning through farmer field schools: A case study of the Taita Hills, Kenya. Winnipeg: Thesis. University of Manitoba.

Palis, F. G. (2006). The role of culture in farmer learning and technology adoption: A case study of farmer field schools among rice farmers in Central Luzon, Philippines. Agriculture and Human Values, 23(4), 491-500.

Palis, F. G., Morin, S., \& Hossain, M. (2005). Social capital and geography of learning: Roles in accelerating the spread of integrated pest 
management. Journal of Agricultural Education and Extension, $11(1-4), 27-37$.

Pananurak, P. (2010). Impact assessment of farmer field schools in cotton production in China, India and Pakistan. Pesticide Policy Project, Special Issue Publication Series, No. 14. Hanover: Inst. Of development and agricultural economics.

Pemsl, D. E., Waibel, H., \& Witt, R. (2006). Diffusion of information among small-scale farmers in Senegal: The concept of farmer field schools. Berlin: Proceedings of the German Development Economics Conference.

Pontius, J. C., Dilts, D. R., \& Bartlett, A. (2002). Ten years of IPM training in Asia: from farmer field school to community IPM. http://www.fao.org/docrep/005/ac834e/ac834e00.htm. Bangkok: Food and agriculture organization.

Praneetvatakul, S., \& Waibel, H. (2006) Impact assessment of farmer field school using a multi period panel data model. In International Association of Agricultural Economists, Gold Coast, (pp. 12-18): Citeseer.

Pretty, J., \& Ward, H. (2001). Social capital and the environment. World Development, 29(2), 209-227.

Rebaudo, F., \& Dangles, O. (2011). Coupled information diffusion-pest dynamics models predict delayed benefits of farmer cooperation in pest management programs. PLoS Computational Biology, 7(10), e1002222.

Regmi, P. P., Bahadur, G., \& Bhattarari, H. P. (2014). Impact assessment of National Integrated Pest Management (NIPM) program in Nepal. Final report. Lalitpur: Nepal Development Research Institute.

Rejesus, R. M., Mutuc, M. E. M., Yasar, M., Lapitan, A. V., Palis, F. G., \& Chi, T. T. N. (2012). Sending Vietnamese rice farmers back to school: Further evidence on the impacts of farmer field schools. Canadian Journal of Agricultural Economics, 60(3), 407-426.

Rejesus, R. M., Palis, F. G., Lapitan, A. V., Chi, T. T. N., \& Hossain, M. (2009). The impact of integrated pest management information dissemination methods on insecticide use and efficiency: Evidence from rice producers in South Vietnam. Review of Agricultural Economics, 31(4), 814-833.

Ricker-Gilbert, J., Norton, G. W., Alwang, J., Miah, M., \& Feder, G. (2008). Cost-effectiveness of alternative integrated pest management extension methods: An example from Bangladesh. Review of Agricultural Economics, 30(2), 252-269.

Rogers, C. (1969). Freedom to learn. Columbus: Merrill.

Röling, N. (2002) Issues and challenges for FFS: an introductory overview. In International Learning Workshop on FFS: Emerging issues and challenges, 21-25 October 2002, Yogyakarta, (pp. 21-25).

Sanglestsawai, S., Rejesus, R. M., \& Yorobe Jr., J. M. (2015). Economic impacts of integrated pest management (IPM) farmer field schools (FFS): Evidence from onion farmers in the Philippines. Agricultural Economics, 46(2), 149-162.

Scoones, I. (1998). Sustainable rural livelihoods: A framework for analysis. IDS working paper 72.

Settle, W., Soumaré, M., Sarr, M., Garba, M. H., \& Poisot, A. S. (2014). Reducing pesticide risks to farming communities: Cotton farmer field schools in Mali. Philosophical Transactions of the Royal Society B, 369(1639), 20120277.

Sharifi, A. (2016). A critical review of selected tools for assessing community resilience. Ecological Indicators, 69, 629-647.

Sharma, R., Peshin, R., Shankar, U., Kaul, V., \& Sharma, S. (2015). Impact evaluation indicators of an integrated Pest management program in vegetable crops in the subtropical region of Jammu and Kashmir, India. Crop Protection, 67, 191-199.

Sherwood, S., Schut, M., \& Leeuwis, C. (2012). Learning in the social wild: Farmer field schools and the politics of agricultural science and development in Ecuador. In H. R. Ojha, A. Hall, \& R. Sulaiman (Eds.), Adaptive collaborative approaches in natural resources governance: Rethinking participation, learning and innovation (pp. 102-137). London: Routledge.

Swindale, A., \& Bilinsky, P. (2006a). Development of a universally applicable household food insecurity measurement tool: Process, current status, and outstanding issues. Journal of Nutrition, 136(5), 1449S-1452S

Swindale, A., \& Bilinsky, P. (2006b). Household dietary diversity score (HDDS) for measurement of household food access: Indicator guide. Food and nutrition technical assistance project. Washington, DC: Academy for Educational Development.

Thakur, A. K., Uphoff, N. T., \& Stoop, W. A. (2016). Scientific underpinnings of the system of Rice intensification (SRI): What is known so far? In Advances in Agronomy (Vol. 135, pp. 147-179): Elsevier.

Todo, Y., \& Takahashi, R. (2013). Impact of farmer field schools on agricultural income and skills: Evidence from an aid-funded project in rural Ethiopia. Journal of International Development, 25(3), 362-381.

Tripp, R., Wijeratne, M., \& Piyadasa, V. H. (2005). What should we expect from farmer field schools? A Sri Lanka case study. World Development, 33(10), 1705-1720.

Tsiboe, F., Dixon, B. L., Nalley, L. L., Popp, J. S., \& Luckstead, J. (2016). Estimating the impact of farmer field schools in subSaharan Africa: The case of cocoa. Agricultural Economics, 47(3), 329-339.

UN. (2018). The sustainable development goals report 2018. New York: United Nations.

Van den Berg, H. (2004). IPM farmer field schools: A synthesis of 25 impact evaluations. Rome: FAO.

van den Berg, H., \& Jiggins, J. (2007). Investing in farmers: The impacts of farmer field schools in relation to integrated pest management. World Development, 35(4), 663-686.

Van Rijn, F., Burger, K., \& Den Belder, E. (2012). Impact assessment in the sustainable livelihood framework. Development in Practice, 22(7), 1019-1035.

Waarts, Y., Dengerink, J., Puister-Jansen, L., van Rijn, F., \& Onduru, D. (2016). Final impact evaluation of Farmer Field School implementation in the smallholder tea sector in Kenya, 2009-2016 (Vol. 2016-044): Wageningen economic research.

Waarts, Y., Ge, L., Ton, G., \& Jansen, D. M. (2012). Sustainable tea production in Kenya; impact assessment of Rainforest Alliance and farmer field school training. LEI report 2012-043. The Hague: LEI, part of Wageningen UR.

Waddington, H., Snilstveit, B., Hombrados, J. G., Vojtkova, M., Anderson, J., \& White, H. (2014). Farmer field schools for improving farming practices and farmer outcomes in low-and middle-income countries: A systematic review. Campbell Systematic Reviews, 10(6).

Weatherhead, M. (2016). Social cost benefit analysis of CARE International's pathways program: Technical report. London: NEF Consulting.

Weatherhead, M., Mariam, S., Arnold, S., \& Freeman, A. (2016). Social cost benefit analysis of CARE International's pathways program. London: NEF Consulting.

Weinhardt, L. S., Galvao, L. W., Yan, A. F., Stevens, P., Mwenyekonde, T. N., Ngui, E., et al. (2016). Mixed-method quasi-experimental study of outcomes of a large-scale multilevel economic and food security intervention on HIV vulnerability in rural Malawi. AIDS and Behavior, 21(3), 712-723.

Westendorp, A. B. (2012). The contribution of farmer field schools to rural development in Nepal. PhD Thesis. Wageningen: Wageningen University. 
Witt, R., Pemsl, D. E., \& Waibel, H. (2008). The farmer field school in Senegal: Does training intensity affect diffusion of information? Journal of International Agricultural and Extension Education, 15(2), 47-60.

Wu, L. (2010). Farmer field school and Bt cotton in China: An economic analysis. PhD thesis. University of Hannover. Pesticide Policy Project Publication Series Special Issue, Hanover.

Yamazaki, S., \& Resosudarmo, B. P. (2008). Does sending farmers back to school have an impact? Revisiting the issue. The Developing Economies, 46(2), 135-150.

Yang, P., Liu, W., Shan, X., Li, P., Zhou, J., Lu, J., \& Li, Y. (2008). Effects of training on acquisition of pest management knowledge and skills by small vegetable farmers. Crop Protection, 27(12), 1504-1510.

Yorobe Jr., J. M., Rejesus, R. M., \& Hammig, M. D. (2011). Insecticide use impacts of integrated pest management (IPM) farmer field schools: Evidence from onion farmers in the Philippines. Agricultural Systems, 104(7), 580-587.

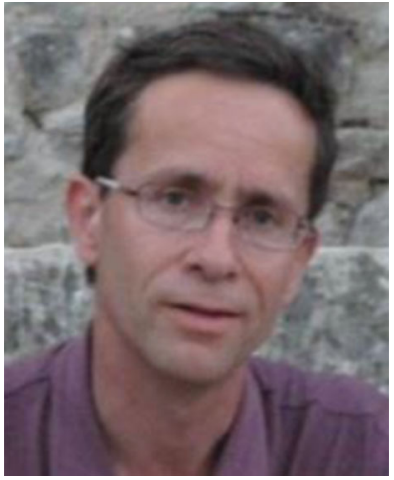

Henk van den Berg works as freelancer and as visiting scientist at Wageningen University, The Netherlands, on integrated approaches for control of agricultural pests and vectors of human diseases. Henk started working as agricultural entomologist in IPM projects based in East Africa (1987-1991), Southeast Asia (1992-1999) and later on in South Asia (1999-2002). From 2000 onwards, he became involved in integrated vector management (IVM) for control of human diseases, notably malaria and dengue. Since 2002, he is based in Europe, where his focus has broadened to include policy development, curriculum development, guidelines development, community participation, and programme evaluation.

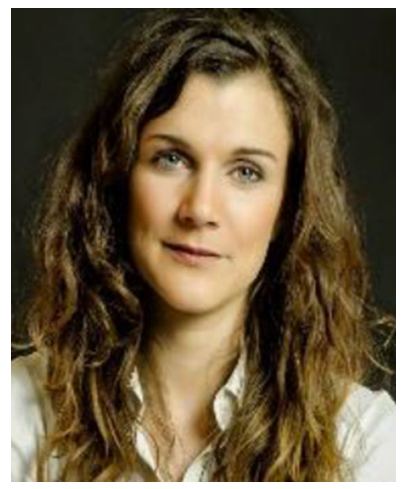

Suzanne Phillips works as a consultant at the Food and Agriculture Organization (FAO) in Rome, Italy, focusing on farmer field schools (FFS) and community-based approaches to climate change adaptation. While at the FAO, Suzanne has worked on developing tools to improve the quality of farmer field school activities and on building households' climate resilience. Before joining the FAO in 2013, Suzanne worked at European Commission and at the Technical Centre for Agricultural and Rural Cooperation (CTA), based in Brussels, Belgium. She holds a MSc in Environment and Development and BA in Biological Sciences.

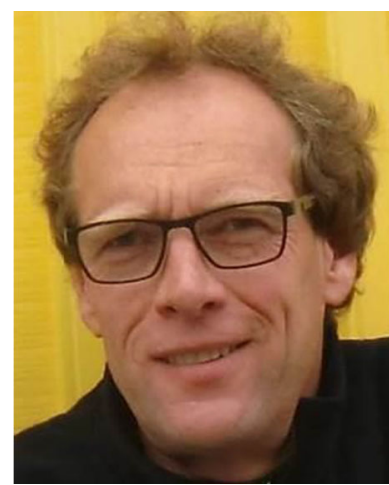

Marcel Dicke is professor of Entomology at Wageningen University, The Netherlands, focussing on the ecology of insectplant interactions. His research focusses on plant-herbivore interactions and multitrophic interactions between plants, insect herbivores, microbes and carnivorous enemies of insect herbivores. Moreover, he studies how insects can be used to convert organic waste streams into high-quality protein sources for animal feed and human food. His research is characterized by multidisciplinary, interdisciplinary and transdisciplinary approaches. He is elected member of the Royal Netherlands Academy of Arts and Sciences, received the Spinoza Prize - the highest scientific award in The Netherlands - for his research programme as well as the Eureka award for Science communication from the Netherlands Organisation for Scientific Research (NWO).

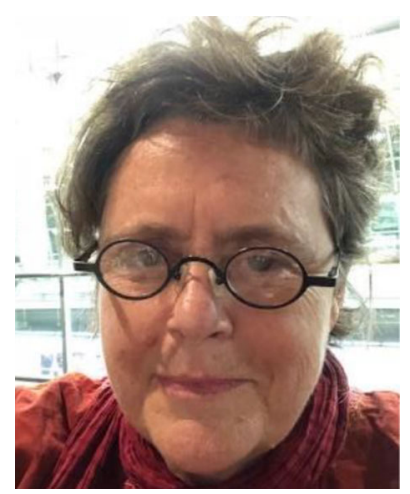

Marjon Fredrix works as agricultural officer for the plant production and protection division in FAO Rome, supporting integrated pest management, sustainable agriculture and farmer field schools. Marjon started working on farmer field schools and IPM in 1989 based in a FAO field project in Asia. From 1998 she provides support to field teams and projects in Africa, Near East, Asia and Latin America to develop and implement farmer field school programmes on a widening range of topics. Her experience covers working with communities and field technicians to develop farmer field school programmes, capacity development and programme implementation. 